\title{
Production performance and milk fatty acid profile in grazing dairy cows offered ground corn or liquid molasses as the sole supplemental nonstructural carbohydrate source
}

\author{
A. F. Brito, ${ }^{* 1}$ K. J. Soder, † P. Y. Chouinard, $\ddagger$ S. F. Reis, ${ }^{*}$ S. Ross, ${ }^{*}$ M. D. Rubano, $†$ and M. D. Casler§ \\ *Department of Agriculture, Nutrition, and Food Systems, University of New Hampshire, Durham 03824 \\ †Pasture Systems and Watershed Management Research Unit, USDA-Agricultural Research Service, University Park, PA 16802 \\ ‡Département des Sciences Animales, Université Laval, Québec City, QC, Canada, G1V 0A6 \\ §Dairy Forage Research Center, USDA-Agricultural Research Service, Madison, WI 53706
}

\begin{abstract}
The objective of this study was to compare the effects of ground corn or liquid molasses fed as the sole supplemental nonstructural carbohydrate (NSC) source on production performance, milk fatty acid (FA) profile, grazing behavior, and $\mathrm{N}$ metabolism in grazing dairy cows. A strip-grazing management system was used, with cows offered a new strip of fresh herbage after each milking, resulting in approximately $16 \mathrm{~h}$ of access to pasture daily. Animals were fed a diet formulated to yield an 86:14 forage-to-concentrate ratio consisting [dry matter (DM) basis] of $74 \%$ mixed grass-legume herbage, $12 \%$ mixed-mostly legume baleage, $12 \%$ NSC source, and $2 \%$ mineral-vitamin premix. Twenty Jersey cows averaging (mean \pm standard deviation) $121 \pm 73$ $\mathrm{d}$ in milk in the beginning of the study were randomly assigned to 1 of 2 herbage supplementation treatments: (1) baleage plus ground corn $(\mathrm{B}+\mathrm{GC})$ or (2) baleage + liquid molasses $(\mathrm{B}+\mathrm{LM})$. Both NSC sources were fed at a flat rate of $1.6 \mathrm{~kg}$ of $\mathrm{DM} / \mathrm{cow}$ daily. The study lasted from June to September for a total of $15 \mathrm{wk}$ with data and sample collection conducted in wk 3, 7, 12, and 15. Milk samples for FA analysis were collected in wk $2,4,6,8,9,11$, and 13 . Data were analyzed using the MIXED procedure of SAS (SAS Institute Inc., Cary, NC) for a randomized complete block design with repeated measures over time. Treatment $\times$ week interactions were observed for supplement DM intake, milk urea $\mathrm{N}$, bite rate, urinary excretion of uric acid, and milk FA (e.g., 17:0, 18:0, cis-9,trans-11 18:2). Supplement DM intake was greatest in cows fed $\mathrm{B}+\mathrm{LM}$ in wk 7, 12, and 15. Compared with cows fed B+GC, those fed $\mathrm{B}+\mathrm{LM}$ had lower concentrations of milk urea $\mathrm{N}$ in wk 7 and 15. Milk yield, concentrations and yields
\end{abstract}

Received January 19, 2017.

Accepted June 5, 2017.

${ }^{1}$ Corresponding author: andre.brito@unh.edu of milk components, and plasma concentrations of essential AA, except Met, which was lowest with feeding $\mathrm{B}+\mathrm{LM}$, were not affected by supplementation. The plasma concentration of urea $\mathrm{N}$ was lowest with feeding $\mathrm{B}+\mathrm{LM}$. Cows fed $\mathrm{B}+\mathrm{GC}$ spent more time grazing than those fed B+LM. Feeding B+GC increased cis-9 18:1 FA and most trans-18:1 FA in milk, whereas B+LM increased $\Sigma$ odd-chain FA, $\Sigma$ n-3 FA, and the trans-11 18:1 to trans-10 18:1 ratio, and decreased the n-6 to n-3 ratio. Based on current results, B+LM can entirely replace $\mathrm{B}+\mathrm{GC}$ without negatively affecting milk yield or yields and concentrations of milk fat and true protein, while decreasing milk urea $\mathrm{N}$, plasma urea $\mathrm{N}$, and the milk trans-11 18:1 to trans-10 18:1 ratio, and increasing $\Sigma$ n-3 FA.

Key words: grazing dairy cow, ground corn, liquid molasses, milk fatty acid

\section{INTRODUCTION}

Previous work demonstrated that ME supply was the single most limiting factor to support moderate to high milk yield under grazing conditions in the northeastern United States (Kolver and Muller, 1998; Soder et al., 2012; Hafla et al., 2016). Low herbage DMI and a high concentration of soluble protein relative to NSC in typical grass-legume pasture mixtures used in the Northeast are among factors that limit milk yield in grazing dairy cows (Bargo et al., 2003). Therefore, supplementation with NSC sources may be needed to increase milk yield and milk protein synthesis in dairy cows offered herbage-based diets.

There is ongoing interest in the use of sugarcane molasses in both conventional (Broderick and Radloff, 2004; Martel et al., 2011; Siverson et al., 2014) and organically certified (Soder et al., 2012; Brito et al., 2015; Ghedini et al., 2016) dairy systems in the United States. Soder et al. (2012) reported that organically certified dairies in the northeastern United States are 
feeding liquid molasses as the sole supplemental NSC source to grazing cows in amounts ranging (DM basis) from 1.1 to $2.4 \mathrm{~kg} /$ cow daily. Interestingly, liquid molasses is the only supplemental NSC source allowed to be used by organic dairy farmers who are currently shipping "grass-fed" milk to selected processors (e.g., Organic Valley, La Farge, WI) in the United States. However, inconsistent results in milk yield, nutrient utilization, BCS, and animal health have been reported when feeding moderate to high amounts of molasses to grazing (Soder et al., 2012; Higgs et al., 2013) and confined (Broderick and Radloff, 2004; Brito et al., 2015; Ghedini et al., 2016) dairy cows. Thus, these inconsistent results and limited data regarding the effects of ground corn or liquid molasses as the sole supplemental NSC source on milk yield and composition in grazing dairy cows warrant further investigation. There is also limited information about the effect of liquid molasses or ground corn on milk fatty acid (FA) profile throughout the grazing season.

The objectives of the current study were to evaluate the effects of ground corn or liquid molasses as the sole supplemental NSC source on milk yield and composition, milk FA profile, grazing behavior, and $\mathrm{N}$ metabolism in dairy cows offered mixed grass-legume herbage as the major forage source. We hypothesized that compared with ground corn, liquid molasses would better match herbage RDP, resulting in increased milk yield and decreased MUN and plasma urea N (PUN) because sucrose is more rapidly degraded in the rumen than starch. We also hypothesized that these 2 NSC sources would lead to marked changes in milk FA profile because of expected differences between ground corn and liquid molasses on intake of 18-C FA and ruminal fermentation processes.

\section{MATERIALS AND METHODS}

The University of New Hampshire Institutional Animal Care and Use Committee approved all experimental procedures (IACUC\# 100414). The experiment was carried out at the University of New Hampshire Burley-Demeritt Organic Dairy Research Farm (Lee, $\mathrm{NH} ; 43^{\circ} 10^{\prime} \mathrm{N}, 70^{\circ} 99^{\prime} \mathrm{W}$ ) from June 7 to September 19 , 2010, for a total of $15 \mathrm{wk}$ or $105 \mathrm{~d}$.

\section{Animals, Experimental Design, and Diets}

Ten multiparous organically certified Jersey cows averaging (mean $\pm \mathrm{SD}$ ) $21.3 \pm 4.1 \mathrm{~kg}$ of milk/d, $65 \pm$ $57 \mathrm{DIM}$, and $415 \pm 25 \mathrm{~kg}$ of BW, and 10 primiparous organically certified Jersey cows averaging $12.8 \pm 5 \mathrm{~kg}$ of milk/d, $177 \pm 33 \mathrm{DIM}$, and $346 \pm 19 \mathrm{~kg}$ of BW in the beginning of the study were used. Animals were fed a diet formulated to yield an 86:14 forage-to-concentrate ratio using the NRC (2001) ration evaluation software. The forage portion of the diet was formulated to contain (DM basis): $74 \%$ mixed grass-legume herbage and 12\% mixed-mostly legume baleage, which was cut and preserved in plastic-wrapped bales as previously described (Resende et al., 2015). Fresh herbage was supplemented with baleage plus ground corn $(\mathbf{B}+\mathbf{G C})$ or baleage + sugarcane liquid molasses $(\mathbf{B}+\mathbf{L M})$, with the NSC sources offered at a daily flat rate of $1.6 \mathrm{~kg}$ of $\mathrm{DM} / \mathrm{cow}$ formulated at $12 \%$ of diet DM. A mineral and vitamin premix (formulated at $2 \%$ of diet DM) containing (as fed, $/ \mathrm{kg}) 104 \mathrm{~g}$ of Ca, $40 \mathrm{~g}$ of Mn, $52 \mathrm{~g}$ of Zn, 8,270 mg of $\mathrm{Fe}, 13,200 \mathrm{mg}$ of $\mathrm{Cu}, 950 \mathrm{mg}$ of I, 1,136 IU of vitamin A, $340 \mathrm{IU}$ of vitamin $\mathrm{D}$, and $5,681 \mathrm{IU}$ of vitamin $\mathrm{E}$ was available to all cows while on pasture and at the barn.

Cows were paired ( $\mathrm{n}=10$ pairs) and each pair was balanced by parity, DIM, and milk yield. Within pair, cows were randomly assigned to $\mathrm{B}+\mathrm{GC}$ or $\mathrm{B}+\mathrm{LM}$ supplementation to an herbage-based diet. Cows assigned to the $\mathrm{B}+\mathrm{GC}$ treatment averaged (mean $\pm \mathrm{SD}$ ) $17.7 \pm$ $5.4 \mathrm{~kg}$ of milk/d, $131 \pm 82 \mathrm{DIM}$, and $376 \pm 45 \mathrm{~kg}$ of $\mathrm{BW}$, whereas those assigned to the $\mathrm{B}+\mathrm{LM}$ treatment averaged $17.7 \pm 4.4 \mathrm{~kg}$ of milk/d, $112 \pm 66$ DIM, and $385 \pm 39 \mathrm{~kg}$ of BW in the beginning of the study. With the exception of milk samples for FA analyses (see below), all remaining data and samples were collected during wk 3 (June 21 to 27), wk 7 (July 19 to 25), wk 12 (August 23 to 29), and wk 15 (September 13 to 19).

After each milking, cows had access to a beddedpack barn with dried pine shavings as bedding material and were maintained in the same pen separated from the remaining cows in the herd. The bedded area (132 $\mathrm{m}^{2}$ ) opens to a $478-\mathrm{m}^{2}$ concrete-floor outdoor lot (total pen area $=610 \mathrm{~m}^{2}$ ) and a roof-covered feeding station equipped with electronic recognition Calan doors system (American Calan Inc., Northwood, NH) located at the opposite end of the bedding. Before each feeding, baleage was placed into 121-L containers (Rubbermaid Commercial Products, Saratoga Springs, NY) and weighed on a portable digital scale (Rubbermaid Pelouze Digital Receiving Scale) with $0.1-\mathrm{kg}$ readability. Both NSC supplements and baleage were offered twice daily at approximately 0630 and $1630 \mathrm{~h}$. Ground corn was placed in small feed tubs and offered to the cows concomitantly with baleage, whereas liquid molasses was top-dressed on the baleage as cows refused to consume it directly from the tubs. Orts were collected daily before the morning and afternoon feedings and weighed as done for the baleage. Supplement intake (i.e., $\mathrm{B}+\mathrm{GC}$ or $\mathrm{B}+\mathrm{LM}$ ) was recorded by subtracting the amount of orts from that of supplement offered daily. Body weight was recorded after the afternoon milking for 3 consecutive $\mathrm{d}$ before $\mathrm{d} 1$ of the experi- 
ment and during the last $3 \mathrm{~d}$ of each sampling week to compute BW change. Animals had free access to water throughout the duration of the experiment.

\section{Paddock Allocation, and Herbage and Feed Sampling and Analyses}

During the first $3 \mathrm{wk}$ before each sampling week, the cows used in the study $(\mathrm{n}=20)$ and the remaining lactating animals $(\mathrm{n}=30)$ of the herd grazed together in a single group. During each 7-d sampling week, cows assigned to the study were divided in 2 groups according to their respective treatments and grazed separately in adjacent paddocks. A strip-grazing management system using a temporary electrified fencing system (polywire and step-in fence posts) was used, with animals offered a new strip of fresh herbage after each milking, resulting in approximately $16 \mathrm{~h}$ of access to pasture daily. To measure herbage DM disappearance, samples of preand post-grazing herbage mass were collected along 3 transects (5 clippings/transect) in each paddock using handheld electric clippers (Cordless Grass Shear model UM1000D; Makita Co., La Mirada, CA) and a 0.25$\mathrm{m}^{2}$ quadrat. Herbage within the quadrat frame was clipped to approximately $2 \mathrm{~cm}$ above the ground level and both fresh and dried (forced-air oven at $55^{\circ} \mathrm{C}$ for $48 \mathrm{~h}$ ) weights of each clipping from each transect were recorded. Daily herbage DMI by group of cows was estimated by the difference between pre- and post-grazing herbage mass (referred as pre-post herbage DMI).

Herbage height (pre- and post-grazing) was determined concomitantly with herbage mass measurements, using a ruler to record a total of 15 heights per paddock along 3 transects. Samples $(\mathrm{n}=10)$ for determination of pasture botanical composition were collected in the first d of each sampling week by clipping a 1-m length patch of herbage with hand-held electric clippers (Cordless Grass Shear model UM1000D) following a zig-zag pattern throughout the area set to be grazed by both groups of cows. Samples were brought to the laboratory and separated into grasses, legumes, weeds, and dead material. Next, samples were dried for $48 \mathrm{~h}$ in a forced-air oven set to $55^{\circ} \mathrm{C}$ and finally weighed by functional group. The most predominant grass species were timothy (Phleum pratense L.), orchardgrass (Dactylis glomerata L.), Kentucky bluegrass (Poa pratensis L.), and tall fescue [Schedonorus phoenix (Scop.) Holub], and predominant legume species were red clover (Trifolium pratense L.), white clover (Trifolium repens L.), and alfalfa (Medicago sativa L.).

Samples for determination of herbage nutritional composition were collected twice daily (morning and afternoon samplings) during d 1 and 2 of each sampling week using the hand-plucking method (Kolver and
Muller, 1998) following a zig-zag pattern throughout all paddocks set to be grazed by both groups of cows. All samples were stored in a refrigerator $\left(4^{\circ} \mathrm{C}\right)$, composited by week, and divided into 2 subsamples of equal size. The first subsample was used for DM determination $\left(55^{\circ} \mathrm{C}\right.$ for $\left.48 \mathrm{~h}\right)$ and the second for nutritional composition. Samples of ground corn and liquid molasses were collected during each sampling week, and 1 composite of each supplement was shipped to commercial laboratories. Baleage and ort samples were collected daily during each sampling week, composited by week, and dried $\left(55^{\circ} \mathrm{C}\right.$ for $\left.48 \mathrm{~h}\right)$ before shipping for nutritional analyses.

Dried herbage, baleage, ground corn, and orts were ground through a 1-mm screen using a Wiley mill (Arthur Thomas Philadelphia, PA) and shipped to Dairy One Forage Testing Laboratory (Ithaca, NY) to be analyzed for DM, ash, total N, NDF, ADF, degradable protein, ethanol-soluble carbohydrates (ESC), watersoluble carbohydrates (WSC), and individual minerals by wet chemistry and chromatographic methods (analytical methods available at http://dairyone.com/ wp-content/uploads/2014/02/Forage-Lab-Analytical -Procedures-Listing-Alphabetical-July-2015.pdf; accessed April 6, 2017). Feeds for FA profile were shipped to the Pennsylvania State University (Kevin Harvatine Laboratory, University Park, PA) and analyzed using a gas chromatograph after direct methylation (Sukhija and Palmquist, 1988). All feeds were analyzed for EAA using cation-exchange HPLC coupled with post-column ninhydrin derivatization and quantification with norleucine as the internal standard (method 982.30; AOAC International, 2016) at the University of Missouri Experimental Station Chemical Laboratories (Columbia, MO). Liquid molasses was analyzed for DM, total N, and minerals (Dairy One Forage Testing Laboratory), as well as individual sugars using a Beckman HPLC (Beckman Coulter Inc., Fullerton, CA) equipped with an evaporative light scattering detection system (Analab, Fulton, IL).

\section{Grazing Behavioral Measurements and Analyses}

Grazing behavior was monitored on 14 cows (6 multiparous and 8 multiparous; $\mathrm{n}=7 /$ treatment) while on pasture using IGER Behavior Recorders (Institute of Grassland and Environmental Research, North Wyke, UK; Rutter et al., 1997). To prevent equipment damage in the milking parlor and Calan doors (American Calan Inc.), recorders were fitted immediately before cows were turned out on pasture and removed immediately after they returned. The grazing recorder contains a computer processor that receives signals of jaw movements via a graphite-filled elastic jaw band. 
Behavioral measurements were collected during the last $4 \mathrm{~d}$ of sampling wk 3,12 , and 15 . However, the number of observations per cow throughout the study ranged from 1 to 22 (mean $=9.3$ ) primarily due to breakages of the jaw bands. The number of observations per cow within treatment ranged from 1 to 17 (mean $=9.6$ ) and from 3 to 22 (mean $=9$ ) for $\mathrm{B}+\mathrm{GC}$ and $\mathrm{B}+\mathrm{LM}$ cows, respectively. Behavioral data were analyzed using the GRAZE software (Rutter, 2000). Calculated variables included grazing time $(\mathrm{min} / \mathrm{d})$, total grazing jaw movements $(\Sigma$ total number of bites + total number of chews), ruminating time $(\mathrm{min} / \mathrm{d})$, idling time $(\mathrm{min} / \mathrm{d})$, total number of bites/day, and bite rate (bites/min during active grazing bouts).

\section{Milk Sampling and Analyses}

Cows were milked twice daily (0500 and $1600 \mathrm{~h}$ ) with milk yield recorded at each milking throughout the experiment. Milk samples were collected for 4 consecutive milkings during the first $3 \mathrm{~d}$ of each sampling week, preserved in tubes containing 2-bromo-2-nitropropan-1,3 diol, pooled by cow according to afternoon and morning milk weights, refrigerated at $4^{\circ} \mathrm{C}$, and shipped to Dairy One Cooperative Inc. (Ithaca, NY) for analyses of fat, true protein, lactose, TS, and MUN by Fourier transform infrared spectroscopy using a MilkoScan model 6000 (Foss Inc., Hillerød, Denmark), and for SCC by flow cytometry in a Fossomatic 5000 (Foss Inc.). Milk samples without preservative were collected during 2 consecutive milkings on June 15 to 16 (wk 2), June 29 to 30 (wk 4), July 13 to 14 (wk 6), July 27 to 28 (wk 8), August 3 to 4 (wk 9), August 17 to 18 (wk 11), and August 31 to September 1 (wk 13). Samples were pooled using the same procedure described above and stored at $-80^{\circ} \mathrm{C}$ until FA analyses. Briefly, lipids were extracted and FAME were prepared by base-catalyzed transmethylation according to the method of Chouinard et al. (1997). Milk FA profile was determined according to Boivin et al. (2013) using a gas chromatograph (Agilent 7890A; Agilent Technologies, Santa Clara, CA) equipped with a 100-m CP-Sil-88 capillary column (0.25 mm i.d., $0.20 \mathrm{~mm}$ film thickness; Agilent Technologies Canada Inc., Mississauga, ON, Canada) and a flame-ionization detector.

\section{Blood and Urine Sampling and Analyses}

Blood samples were taken once daily approximately at $1500 \mathrm{~h}$ in the first $2 \mathrm{~d}$ of each sampling week by venipuncture of the coccygeal vein or artery into 2 daily sets of 10-mL Vacutainer tubes containing 15\% EDTA (Becton Dickinson, Franklin Lakes, NJ). Tubes were placed immediately on ice and centrifuged (Eppendorf Centrifuge model 5810; Eppendorf, Hamburg, Germany) within $2 \mathrm{~h}$ of collection at $3,300 \times g$ for $20 \mathrm{~min}$ at $5^{\circ} \mathrm{C}$. Plasma samples from both days were composited by cow on a volume basis. The plasma from the first set of Vacutainer tubes were stored at $-20^{\circ} \mathrm{C}$ until urea $\mathrm{N}$ and nonesterified FA (NEFA) analyses. Concentration of PUN was determined colorimetrically using the diacetyl-monoxime method (Rosenthal, 1955) with a $\mathrm{UV} /$ visible spectrophotometer set at a wavelength of $540 \mathrm{~nm}$ (Beckman Coulter Inc., Brea, CA). Analysis of plasma concentration of NEFA was performed using the Wako HR Series NEFA-HR (2) kit (Wako Chemicals USA Inc., Richmond, VA) with a chromate microplate reader set at a wavelength of $550 \mathrm{~nm}$ (Awareness Technology Inc., Palm City, FL). Plasma aliquots (4 $\mathrm{mL}$ ) taken from the second set of Vacutainer tubes were transferred to $40-\mathrm{mL}$ glass culture tubes containing 1 $\mathrm{mL}$ of $15 \%$ sulfosalicylic acid solution (wt/vol) followed by an additional centrifugation $(2,155 \times g$ for 20 min at $\left.4^{\circ} \mathrm{C}\right)$. Aliquots of deproteinized plasma $(1.8 \mathrm{~mL}$ over $2 \mathrm{~d}$ ) obtained during wk 3 and 15 were transferred to cryovials and stored at $-80^{\circ} \mathrm{C}$ until sent to the University of Missouri Experimental Station Chemical Laboratories for EAA analyses following the methods of Deyl et al. (1986) and Fekkes (1996) and using cation-exchange HPLC as reported above.

Spot samples of urine were collected twice daily before the morning and afternoon milkings for 2 consecutive days (d 3 and 4 of each sampling week) by stimulation of the pudendal nerve massaging the area below the vulva. Upon collection, $8 \mathrm{~mL}$ of urine was acidified with $400 \mu \mathrm{L}$ of $6 \mathrm{~N} \mathrm{HCl}$ per time point and then pooled over the $2 \mathrm{~d}$ to generate 1 sample per cow for each sampling week. Urine samples were stored at $-20^{\circ} \mathrm{C}$ in $50-\mathrm{mL}$ centrifuge tubes until analyzed for total $\mathrm{N}$, creatinine, allantoin, and uric acid. Concentration of total $\mathrm{N}$ in urine was assessed by micro-Kjeldahl analysis (Dairy One Forage Testing Laboratory). Creatinine concentration was measured colorimetrically using a commercially available kit (Cayman Chemical Co., Ann Arbor, MI) with a chromate microplate reader set at a wavelength of $492 \mathrm{~nm}$ (Awareness Technology Inc.). Allantoin concentration was determined as reported previously (Chen et al., 1992). Measurement of uric acid was performed using the Stanbio Uric Acid LiquiColor kit (procedure \#1045; Stanbio Laboratory, Boerne, TX). Urinary allantoin and uric acid were read at wavelengths of 522 and $520 \mathrm{~nm}$, respectively, on a UV/visible spectrophotometer (Beckman Coulter Inc.). Daily urinary volume and excretion of nitrogenous fractions were estimated from urinary creatinine concentration assuming a constant creatinine excretion rate of 29 
$\mathrm{mg} / \mathrm{kg}$ of BW (Valadares et al., 1999). Urinary excretion of total purine derivatives (PD) was calculated by adding allantoin and uric acid values.

\section{Calculations and Statistical Analyses}

Predicted total DMI was obtained using the NRC (2001) equation as follows:

$$
\begin{gathered}
\text { Predicted total DMI }= \\
\left(0.372 \times 4 \% \mathrm{FCM}+0.0968 \times \mathrm{BW}^{0.75}\right) \\
\times\left(1-\mathrm{e}^{[-0.192 \times(\mathrm{WOL}+3.67)]}\right),
\end{gathered}
$$

where WOL $=$ week of lactation. Herbage DMI was estimated by the difference between predicted total DMI and measured supplement DMI (referred to as calculated herbage DMI). No statistical analyses were done on either calculated herbage DMI or pre-post herbage DMI because cow was not considered as the experimental unit. Predicted total DMI was not analyzed statistically because it was an equation-derived value.

Data were analyzed using the MIXED procedure of SAS (version 9.4; SAS Institute Inc., Cary, NC) according to a randomized complete block design with repeated measures over time. The following model was fitted for all variables with the exception of grazing behavioral measurements:

$$
\mathrm{Y}_{\mathrm{ijk}}=\mu+\mathrm{B}_{\mathrm{i}}+\mathrm{T}_{\mathrm{j}}+\mathrm{W}_{\mathrm{k}}+\mathrm{T} \times \mathrm{W}_{\mathrm{jk}}+\varepsilon_{\mathrm{ijk}},
$$

where $Y_{i j k}=$ dependent variable, $\mu=$ overall mean, $B_{i}$ = fixed effect of ith block (pair of cows), $\mathrm{T}_{\mathrm{j}}=$ fixed effect of jth treatment, $W_{k}=$ fixed effect of kth sampling week, $\mathrm{T} \times \mathrm{W}_{\mathrm{jk}}=$ interaction between $\mathrm{jth}$ treatment and kth week, and $\varepsilon_{\mathrm{ijk}}=$ error term $\sim N\left(0, \sigma^{2}{ }_{\mathrm{e}}\right)$. The SAS command REPEATED was used to model distinct residual variances; among the spatial covariance structures tested [i.e., spatial power, compound symmetry, autoregressive (1), or heterogeneous autoregressive (1)], the one with the lowest Bayesian information criterion was retained in the final model for each variable analyzed. The subject of the repeated measures was defined as cow nested within treatment and it was treated as a random effect in the model. All reported values are least squares means (LSM), with the PDIFF procedure of SAS used to separate means. One primiparous cow assigned to the $\mathrm{B}+\mathrm{LM}$ treatment died before the end of the first sampling week due to illness unrelated to the experimental conditions and her data were not used in the statistical analyses. Significance was declared at $P$ $\leq 0.05$ and trends at $0.05<P \leq 0.10$. The treatment $x$ week interaction term was removed from the model when $P>0.25$.

Grazing behavioral data were analyzed using the MIXED procedure of SAS (version 9.4; SAS Institute Inc.) using a data set obtained from 14 cows across sampling wk 3, 12, and 15 . Because parity was not balanced with respect to either treatment or week, cow was treated as a nested effect within both treatment and week, and parity ( 1 for primiparous and 2 for multiparous) was included as a single covariate to adjust treatment and week LSM to a constant parity level. Parity and the treatment $\times$ week interaction were retained in all models based on Bayesian information criterion comparison against reduced models, unless when $P>0.25$ for the interaction term. Residuals from all models were investigated for normality and homogeneity of errors and found to satisfactorily meet both of those assumptions.

\section{RESULTS AND DISCUSSION}

\section{Nutritional Composition of Herbage and Feeds}

The botanical and nutritional composition of the mixed grass-legume herbage is presented in Table 1. Herbage mass production averaged $2,425 \mathrm{~kg}$ of DM/ha and was within the range observed in the northeastern United States for similar perennial cool-season pastures under organic certification (Dillard et al., 2016). The proportion of grasses was numerically greatest in wk 3 and relatively similar in wk 7,12 , and 15 , whereas that of legumes and weeds was numerically lowest in wk 3 and increased substantially thereafter. Compared with wk 12 and 15, concentrations of CP, ESC, and WSC were numerically greater and those of NDF and ADF numerically lower in herbage collected in wk 3 and 7 , indicating a loss in nutritive value as the grazing season progressed. It is important to note, however, that the nutritive value of the herbage offered herein, including the concentration of macrominerals, was within the range reported for herbage under organic certification in the northeastern United States (Hafla et al., 2016). The proportion of herbage FA fluctuated across the grazing season and may be explained by changes in plant species composition, plant growth stage, and seasonality (Boufaïed et al., 2003; Mir et al., 2006).

The nutritional composition of the mixed-mostly legume baleage, ground corn, and liquid molasses is shown in Table 2. The concentrations of CP, NDF, and ADF in baleage samples averaged 19.6, 47.5, and $36.4 \%$, respectively, indicating moderate to high nutritive value. Similar to fresh herbage, cis-9, cis-12, cis-15 18:3 was the FA with the greatest proportion in baleage samples, which is consistent with previous research 
Table 1. Climatic conditions, herbage height, and botanical and nutritional composition of the mixed grass-legume herbage fed to lactating dairy cows throughout the grazing season ${ }^{1}$

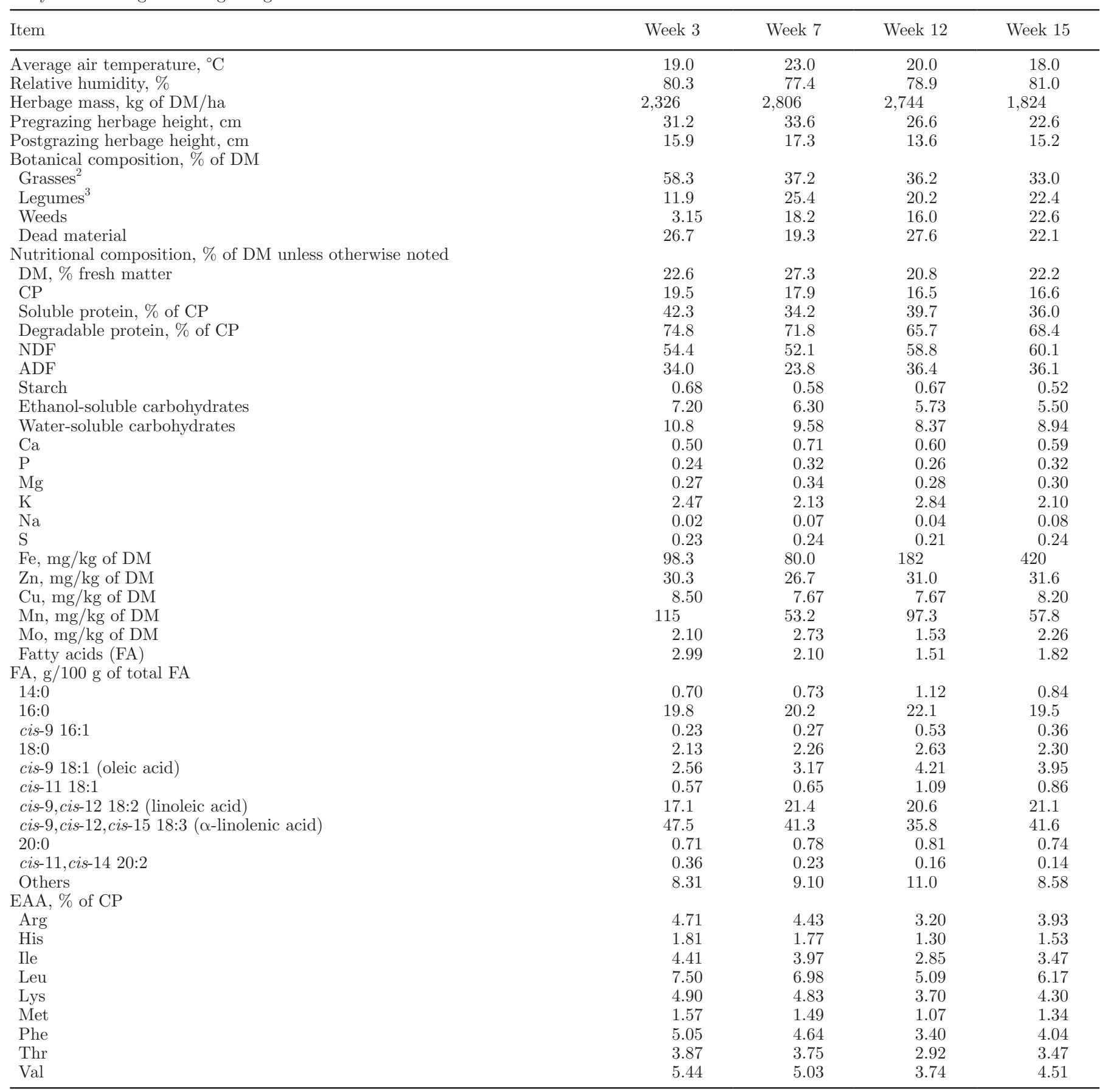

${ }^{1}$ Week 3: June 21 to 27; week 7: July 19 to 25; week 12: August 23 to 29; week 15: September 13 to 19.

${ }^{2}$ Predominant grass species: timothy (Phleum pratense L.), orchardgrass (Dactylis glomerata L.), Kentucky bluegrass (Poa pratensis L.), and tall fescue [Schedonorus phoenix (Scop.) Holub].

${ }^{3}$ Predomint legume species: red clover (Trifolium pratense L.), white clover (Trifolium repens L.), and alfalfa (Medicago sativa L.).

(Boufaïed et al., 2003; Ribeiro et al., 2005). Sucrose was the predominant sugar found in liquid molasses and accounted for $81 \%$ of the total individual sugars. However, the concentrations of sucrose and total sug- ars were 38 and $27 \%$ lower, respectively, in the current study than those reported by Brito et al. (2015), thus indicating a substantial variation in liquid molasses sugar content from source to source. Compared with 
liquid molasses, ground corn had a better EAA profile due to numerically greater concentrations of Lys, Met, and His.

\section{Treatment by Week Interactions}

A treatment $\times$ week interaction was observed for supplement DMI $(P<0.01$; Figure 1a); supplement
DMI did not differ between treatments in wk 3, but was greatest in cows fed B+LM in wk $7(+0.40 \mathrm{~kg} / \mathrm{d}$; $P<0.01)$, wk $12(+0.45 \mathrm{~kg} / \mathrm{d} ; P<0.01)$, and wk 15 $(+0.75 \mathrm{~kg} / \mathrm{d} ; P<0.001)$. Top-dressing liquid molasses on the baleage may have stimulated intake because of improved palatability. In fact, Nombekela et al. (1994) reported that cows preferred TMR with a sweet additive (i.e., sucrose) over a TMR without additive or

Table 2. Nutritional composition (\% of DM unless otherwise noted) of mixed-mostly legume baleage and supplemental NSC sources fed to lactating dairy cows throughout the grazing season ${ }^{1}$

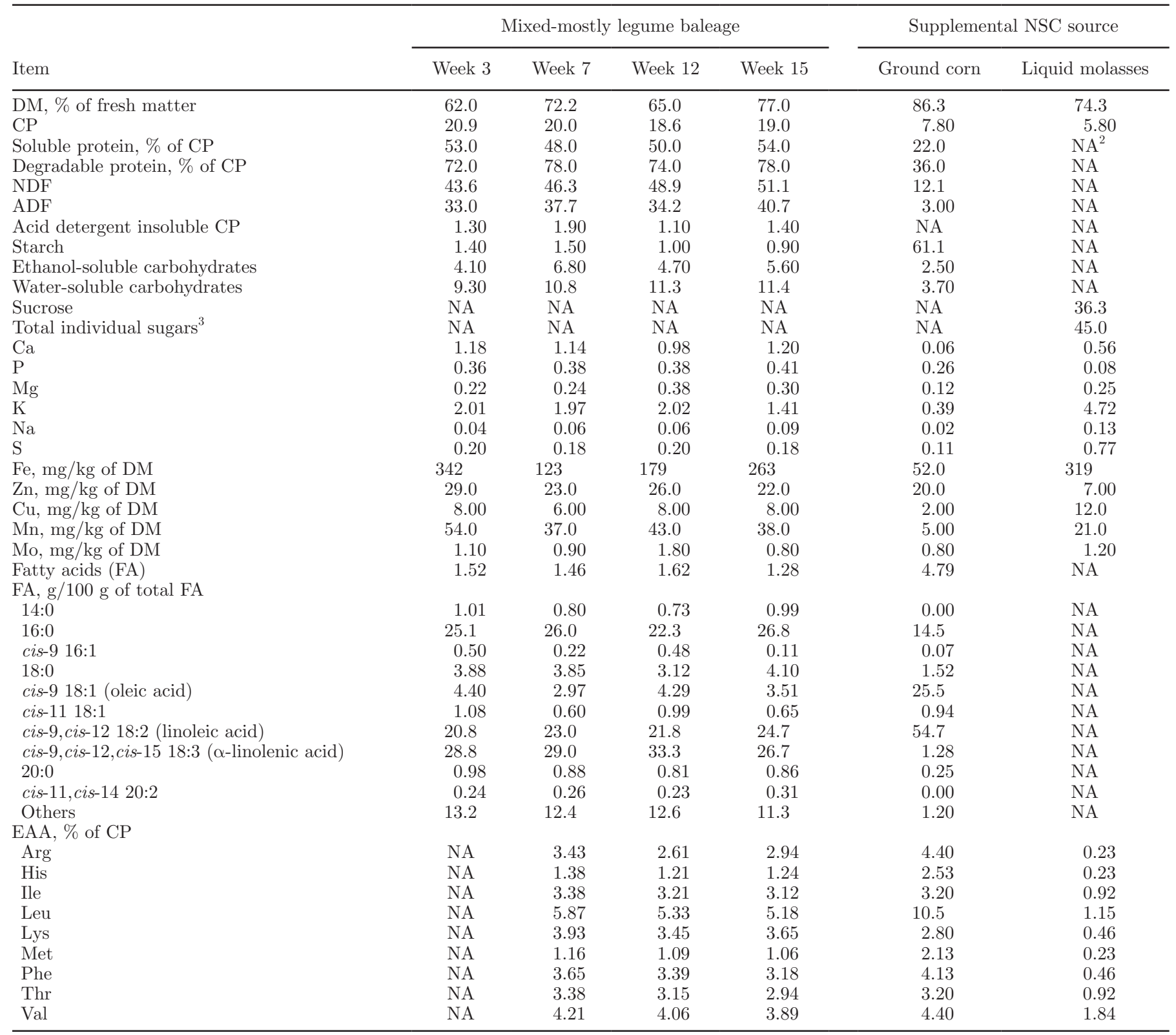

${ }^{1}$ Week 3: June 21 to 27; week 7: July 19 to 25; week 12: August 23 to 29; week 15: September 13 to 19.

${ }^{2}$ Not analyzed.

${ }^{3}$ Total individual sugars $(\%$ of DM $)=$ fructose $(5.16 \%)+$ glucose $(3.10 \%)+$ sucrose $(36.3 \%)+$ maltose $(0.29 \%)+$ stachyose $(0.02 \%)+$ mannitol $(0.16 \%)$. 
a)

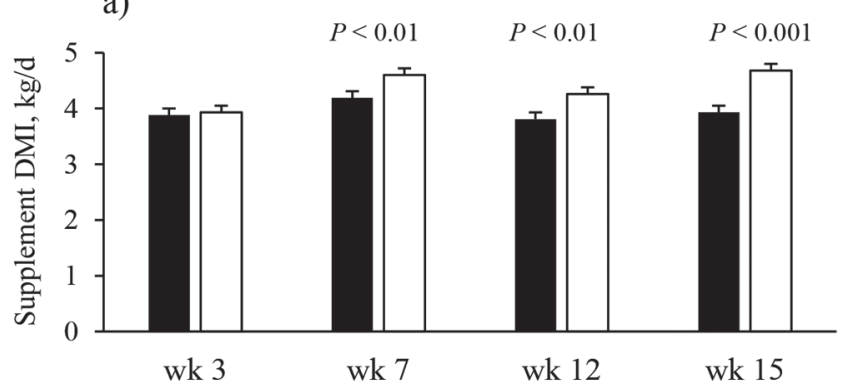

c)

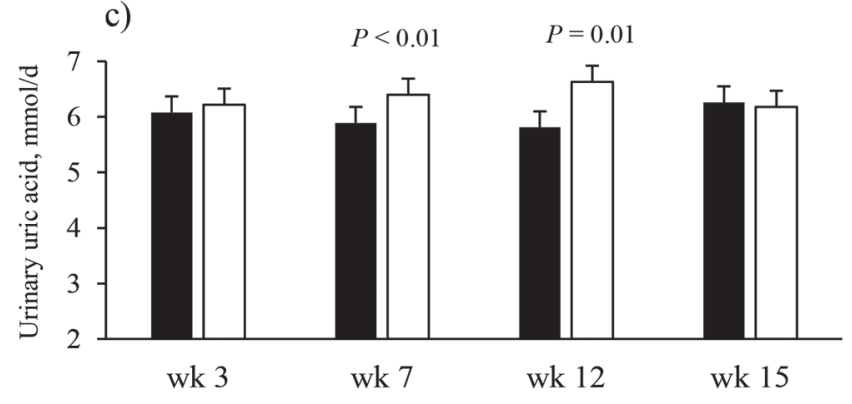

e)

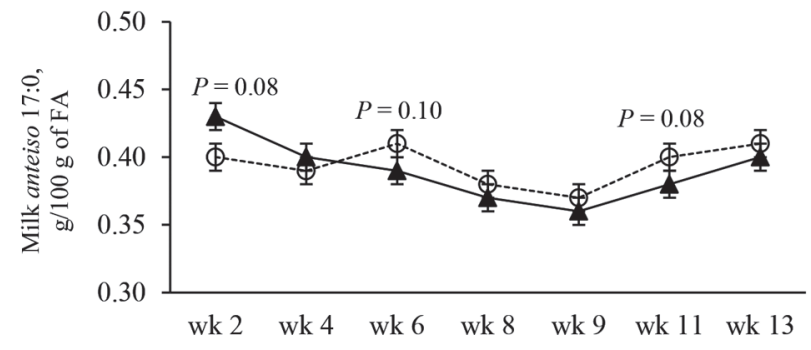

g)



b)



d)



f)

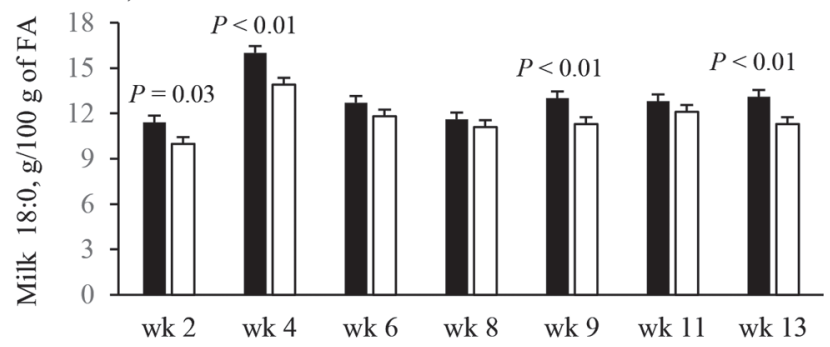

h)



Figure 1. Treatment $\times$ week interactions of different variables in lactating dairy cows grazing mixed grass-legume herbage supplemented with baleage plus ground corn $(\mathrm{B}+\mathrm{GC}$; black bar and $\mathbf{\Delta})$ or baleage plus liquid molasses $(\mathrm{B}+\mathrm{LM}$; white bar and $O)$. (a) Supplement DMI $(P<$ $0.01 ; \mathrm{SEM}=0.12 \mathrm{~kg} / \mathrm{d}) ;(\mathrm{b}) \mathrm{MUN}(P<0.01 ; \mathrm{SEM}=0.52 \mathrm{mg} / \mathrm{dL}) ;(\mathrm{c})$ urinary excretion of uric acid $(P=0.02 ; \mathrm{SEM}=0.29 \mathrm{mmol} / \mathrm{d}) ;(\mathrm{d}) \mathrm{milk}$ 17:0 $[P=0.02 ; \mathrm{SEM}=0.02 \mathrm{~g} / 100 \mathrm{~g}$ of fatty acids $(\mathrm{FA})] ;(\mathrm{e})$ milk anteiso 17:0 $(P=0.04 ; \mathrm{SEM}=0.01 \mathrm{~g} / 100 \mathrm{~g}$ of FA $) ;(\mathrm{f}) \mathrm{milk} 18: 0(P<0.01 ;$ $\mathrm{SEM}=0.45 \mathrm{~g} / 100 \mathrm{~g}$ of FA); $(\mathrm{g})$ milk cis-9,trans-11 18:2 $\left(P=0.04 ; \mathrm{SEM}=0.05 \mathrm{~g} / 100 \mathrm{~g}\right.$ of FA); and $(\mathrm{h}) \Delta^{9}{ }^{-}$-desaturase index 14 (cis-9 14:1/14:0; $P=0.04 ; \mathrm{SEM}=0.44 \mathrm{~g} / \mathrm{g})$. Treatment $\times$ week interaction was declared significant at $P \leq 0.05$ and trends at $0.05<P \leq 0.10$. Significant differences between treatments within week are indicated by $P$-values. The error bars indicate SEM.

that had a sour (i.e., $\mathrm{HCl}$ ), bitter (i.e., urea), or salty (i.e., $\mathrm{NaCl}$ ) additive. However, because ground corn fell through the baleage when poured on top, we decided to offer it in a feed tub, thereby enabling cows to selectively consume either baleage or ground corn. Regardless of the feeding method used, the average concentra- tion (DM basis) of starch in orts from cows fed B+GC $(14.2 \%)$ was numerically greater than that of starch in orts from cows fed B+LM (0.65\%; data not shown). In contrast, the average concentrations (DM basis) of ESC and WSC in orts from cows fed B+GC (4.38 and $9.45 \%$, respectively) were numerically lower than those 
Table 3. Least squares means for urinary volume and excretion of metabolites and plasma concentration of EAA in lactating dairy cows grazing mixed grass-legume herbage supplemented with baleage plus ground corn $(\mathrm{B}+\mathrm{GC})$ or baleage plus liquid molasses $(\mathrm{B}+\mathrm{LM})$

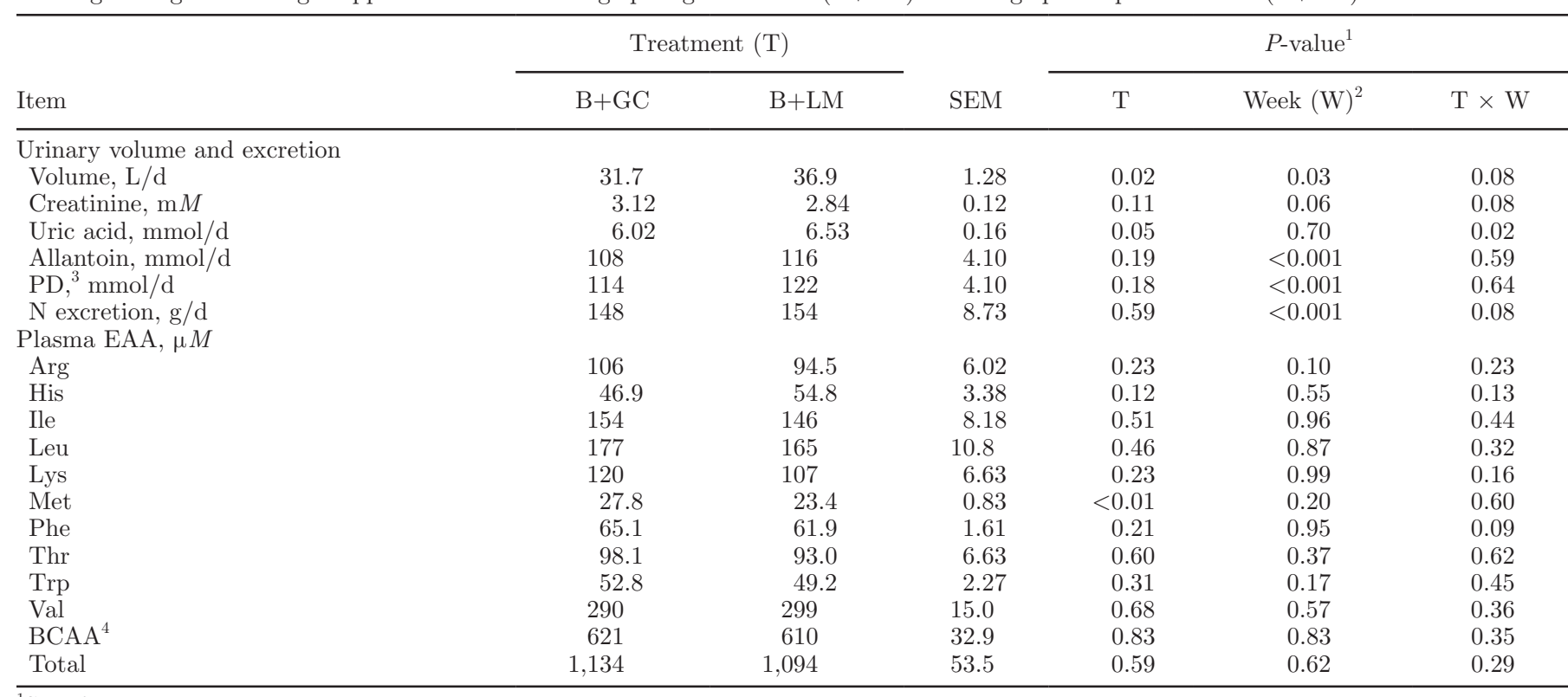

${ }^{1}$ Significance was declared at $P \leq 0.05$ and trends at $0.05<P \leq 0.10$.

${ }^{2}$ Least squares means and SEM for week effects are reported in Supplemental Table S1 (https://doi.org/10.3168/jds.2017-12618).

${ }^{3} \mathrm{PD}=$ purine derivatives (allantoin + uric acid).

${ }^{4} \mathrm{BCAA}=$ branched-chain AA (Ile + Leu + Val).

of ESC and WSC in orts from cows fed B+LM (27.8 and $38.3 \%$, respectively; data not shown). These results collectively indicate that neither NSC supplemental source was entirely consumed by the cows.

Whereas the concentration of MUN was similar between treatments in wk $3($ mean $=13.4 \mathrm{mg} / \mathrm{dL})$ and wk $12($ mean $=11.3 \mathrm{mg} / \mathrm{dL})$, cows fed $\mathrm{B}+\mathrm{LM}$ had the lowest MUN in wk $7(-2 \mathrm{mg} / \mathrm{dL} ; P<0.01)$ and wk 15 $(-2.6 \mathrm{mg} / \mathrm{dL} ; P<0.001 ;$ Figure $1 \mathrm{~b}$; treatment $\times$ week interaction: $P<0.01)$. Decreased MUN can be explained in part by a better match between $\mathrm{NH}_{3}-\mathrm{N}$ released from herbage RDP and fermentable energy from liquid molasses because sucrose is more rapidly degraded in the rumen than starch (Chamberlain et al., 1993). In fact, Broderick et al. (2008) reported a linear decrease in the ruminal concentration of $\mathrm{NH}_{3}-\mathrm{N}$ in lactating dairy cows fed diets where corn starch was replaced by incremental amounts of sucrose. In addition, the concentration of MUN decreased linearly when liquid molasses replaced high-moisture shelled corn (Broderick and Radloff, 2004) or ground corn (Ghedini et al., 2016) in diets of dairy cows. Alternatively, intake and urinary excretion of $\mathrm{K}, \mathrm{Na}$, and $\mathrm{N}$ explained, respectively, 85.8 and $89.8 \%$ of the variance when regressed against observed urinary volume in lactating dairy cows according to Bannink et al. (1999). Spek et al. (2012) reported that feeding incremental amounts of $\mathrm{Na}$ to lactating dairy cows increased linearly the urinary volume and total urinary $\mathrm{N}$ excretion, and decreased linearly the concentration of MUN. Eriksson and Rustas (2014) observed a positive linear relationship between $\mathrm{K}$ intake and urinary volume, whereas a negative linear relationship was found for K intake and MUN in dairy cows. The concentrations of $\mathrm{K}$ and $\mathrm{Na}$ in liquid molasses were, respectively, 12- and 6.5-fold numerically greater than those found in ground corn (Table 2), which coincided with increased $(P=0.02)$ urinary volume $(+5.2 \mathrm{~L} / \mathrm{d}$; Table 3) and decreased MUN (wk 7 and 15) in B+LM versus $\mathrm{B}+\mathrm{GC}$ cows. Elevated $\mathrm{Na}$ and $\mathrm{K}$ intake results in increased renal glomerular filtration rate and a temporary increase in the urinary excretion of urea $\mathrm{N}$, which ultimately decreases PUN and MUN (Spek et al., 2012; Eriksson and Rustas, 2014).

The concentration of MUN in response to NSC supplementation has been inconsistent in grazing studies (Gehman et al., 2006; Higgs et al., 2013). Gehman et al. (2006) reported no difference in the concentration of MUN in cows offered perennial ryegrass (Lolium multiflorum L.) herbage supplemented with a ground corn- or a citrus pulp/molasses-based concentrate, but an increase in MUN was observed when feeding a barley/molasses-based concentrate. Concentration of MUN was also greater in dairy cows grazing mixedmostly perennial ryegrass orally supplemented with 1.5 $\mathrm{kg} / \mathrm{d}$ of a 3:1 molasses:water bolus compared with those supplemented with a ground corn-based concentrate 
(Higgs et al., 2013). Thus, the form in which molasses is supplemented, which included top-dressed on the baleage (current study), incorporated in a concentrate mix (Gehman et al., 2006), or as an oral bolus (Higgs et al., 2013), may help explain the discrepancies in MUN across grazing studies.

A treatment $\times$ week interaction $(P=0.03)$ was observed for bite rate. Bite rate did not differ in wk 3 and averaged 52.6 and 51.9 bites/min when feeding B+GC and $\mathrm{B}+\mathrm{LM}$, respectively (data not shown). However, bite rate tended $(P=0.07)$ to be greater in wk 12 (49.8 vs. $39.1 \mathrm{bites} / \mathrm{min})$ and was greater $(P<0.001)$ in wk 15 (60.1 vs. 33.1 bites/min) in $\mathrm{B}+\mathrm{GC}$ versus $\mathrm{B}+\mathrm{LM}$ cows (data not shown). Increased supplement DMI with feeding $\mathrm{B}+\mathrm{LM}$ versus $\mathrm{B}+\mathrm{GC}$ may have resulted in greater ruminal fill when cows were turned out on pasture, particularly later in the grazing season. This may have led to more selective grazing behavior and less bite rate in cows fed $\mathrm{B}+\mathrm{LM}$ due to more time spent searching for specific herbage species or herbage components (Gregorini et al., 2007, 2009).

Significant treatment $\times$ week interactions were observed for the milk proportions of 17:0 (Figure 1d), anteiso 17:0 (Figure 1e), 18:0 (Figure 1f), cis-14 18:1 (data not shown), cis-9,trans-11 18:2 (Figure 1g), and cis-13,cis-16 22:2 (data not shown), and for the $\Delta^{9}$ -

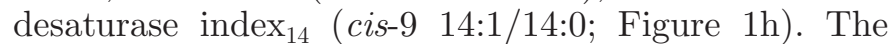
milk proportion of 17:0 (Figure 1d), an odd-chain FA originated primarily from ruminal microorganisms (Fievez et al., 2012), was greatest in cows fed B+LM during wk $6,8,9,11$, and 13 and did not differ between treatments during wk 2 and 4 . Similarly, a treatment $\times$ week interaction was observed for the urinary excretion of uric acid; cows fed $\mathrm{B}+\mathrm{LM}$ showed the greatest output of this PD in wk 7 and 12 (Figure 1c), which also suggest changes in microbial protein synthesis in the rumen. The milk proportion of 18:0 was lowest in cows fed B+LM in wk 2, 4, 9, and 13 (Figure 1f). As reported in Table 2, ground corn contained (DM basis) $4.79 \%$ total FA, with $25.5 \%$ cis-9 $18: 1$ and $54.7 \%$ cis9,cis-12 18:2. Thus, replacing ground corn with liquid molasses reduced the intake of these 2 UFA, resulting in less substrates to be biohydrogenated to $18: 0$ by the ruminal bacteria.

We detected no treatment differences within week for the milk proportions of anteiso 17:0 (Figure 1e) and cis-9,trans-11 18:2 (Figure 1g) or for the $\Delta^{9}$-desaturase index $_{14}$ (cis-9 14:1/14:0; Figure 1h); however, there were temporal differences between treatments with the advance of lactation and grazing season, thereby accounting for these treatment $\times$ week interactions. Overall, the treatment $\times$ week interactions for all FA described herein may be linked to multiple factors. For instance, it is well known that the FA profile of cow milk is generally affected by diet, with most of the variation explained by differences in the amounts of fresh forage and concentrates consumed (Schwendel et al., 2015). In addition to dietary factors, seasonality (Soyeurt et al., 2008; Heck et al., 2009), pasture botanical composition (Soder et al., 2006), stage of lactation (Craninx et al., 2008; Soyeurt et al., 2008), and parity (Soyeurt et al., 2008) have been shown to affect milk FA profile. Therefore, any of these factors and their interrelationships may have contributed to the treatment $\times$ week interactions observed in the present study.

\section{Production Performance, Grazing Behavior, and Plasma and Urinary Metabolites}

Least squares means for the effects of treatments on the urinary excretion of nitrogenous metabolites and plasma concentration of EAA are presented in Table 3 , and LSM for the week effects on these variables are presented in Supplemental Table S1 (https://doi.org/ 10.3168/jds.2017-12618). The urinary excretions of allantoin $($ mean $=113 \mathrm{mmol} / \mathrm{d})$, total $\mathrm{PD}($ mean $=119$ $\mathrm{mmol} / \mathrm{d})$, and total $\mathrm{N}($ mean $=151 \mathrm{~g} / \mathrm{d})$ did not differ between treatments (Table 3). Except for Met, whose plasma concentration was greatest $(+19 \%)$ in cows supplemented with $\mathrm{B}+\mathrm{GC}$, no other significant treatment differences were observed for plasma concentrations of the remaining free EAA, branched-chain AA, and total EAA (Table 3). Because urinary excretion of total PD was similar across treatments, microbial protein synthesis was likely not involved with increased plasma Met concentration in B+GC cows. In addition, duodenal flow of digestible Met was similar (i.e., $21 \mathrm{~g} / \mathrm{d}$; data not shown) between treatments based on the NRC (2001) model. Therefore, despite the 9.3-fold increase in the concentration of Met when comparing ground corn versus liquid molasses (Table 2), the lack of treatment effects on urinary excretion of PD and yields of milk and milk true protein do not fully support the $19 \%$ difference in plasma Met between $\mathrm{B}+\mathrm{GC}$ and $\mathrm{B}+\mathrm{LM}$.

Least squares means for the effects of treatments on milk yield and composition, grazing behavior, BW change, PUN, and plasma NEFA are presented in Table 4 , and LSM for the week effects on these variables are presented in Supplemental Table S2 (https://doi.org/ 10.3168/jds.2017-12618). Predicted total DMI was numerically greater $(+0.8 \mathrm{~kg} / \mathrm{d})$ in cows supplemented with B+LM compared with B+GC (Table 4). Similarly, calculated herbage DMI $(+0.4 \mathrm{~kg} / \mathrm{d})$ and pre-post herbage DMI $(+1.11 \mathrm{~kg} / \mathrm{d})$ were greater in cows fed $\mathrm{B}+\mathrm{LM}$ versus $\mathrm{B}+\mathrm{GC}$ (Table 4). The use of empirical models to predict total DMI such as the NRC (2001) equation may be biased by the limited number of grazing studies included in the data set. However, predicted total DMI 
Table 4. Means $( \pm \mathrm{SD})$ for predicted total DMI and herbage DMI, and least squares means for milk yield and composition, plasma concentrations of urea N (PUN) and nonesterified fatty acids (NEFA), BW change, and grazing behavior in lactating dairy cows grazing mixed grass-legume herbage supplemented with baleage plus ground corn $(\mathrm{B}+\mathrm{GC})$ or baleage plus liquid molasses $(\mathrm{B}+\mathrm{LM})$



estimated by the NRC (2001) did not differ from DMI measured by the chromium oxide method (Bargo et al., 2003), with the advantage that the NRC (2001) equation requires only animal factors. It is also important to note that the pre-post herbage DMI method may be influenced by pasture botanical composition, sward height and density, and sampling errors. Therefore, our herbage DMI data should be interpreted cautiously.

Yields of milk, 4\% FCM, and ECM, as well as the concentrations and yields of milk components (i.e., fat, true protein, lactose, and TS) were not affected by treatments in the present study (Table 4). Gehman et al. (2006) also observed no differences in milk yield, and concentrations and yields of milk components with the exception of milk true protein content, which was greatest, intermediate, or lowest in dairy cows grazing perennial ryegrass supplemented with a concentrate consisting of ground corn, barley-molasses, or citrus pulp-molasses, respectively. Higgs et al. (2013) reported greater concentrations of milk fat, but lower milk yield and concentrations and yields of milk true protein and lactose in dairy cows grazing mixed-mostly perennial ryegrass herbage orally supplemented with a 3:1 molasses:water bolus compared with those supplemented with a ground corn-based concentrate.

Milk SCC $($ mean $=121,000$ cells $/ \mathrm{mL})$, plasma concentration of NEFA (mean $=242 \mathrm{mEq} / \mathrm{L}$ ), and BW gain $($ mean $=+0.30 \mathrm{~kg} / \mathrm{d}$ ) did not differ between treatments (Table 4). In contrast, the concentration of PUN was lower $(P<0.01)$ in cows fed $\mathrm{B}+\mathrm{LM}$ than in those fed $\mathrm{B}+\mathrm{GC}$ (Table 4), possibly because of an improved balance between ruminally fermentable energy and herbage RDP supply. Liquid molasses fed as the sole supplemental NSC source also led to a lower concentration of PUN compared with ground corn in dairy cows offered grass hay-based diets (Brito et al., 2015). However, Higgs et al. (2013) reported that grazing cows orally supplemented with a 3:1 molasses: water bolus had greater BUN than those supplemented with a ground corn-based concentrate. Decreased PUN 
may be also associated with increased intake of $\mathrm{K}$ and $\mathrm{Na}$ in cows fed $\mathrm{B}+\mathrm{LM}$ versus $\mathrm{B}+\mathrm{GC}$, as previously discussed. Overall, differences in the concentration of sucrose among molasses sources, NSC concentration of the herbage offered, and administration form of molasses and ground corn may help explain these discrepant results in circulating urea $\mathrm{N}$, and milk yield and composition.

The time cows spent grazing daily $(+15 \% ; P<0.01)$, as well as the total number of grazing jaw movements $(+11 \% ; P<0.01)$ and bites $(+48 \% ; P<0.001)$ increased with feeding B+GC versus B+LM (Table 4), suggesting that $B+G C$ cows were less selective when grazing by taking smaller, narrower, and shallower bites to capitalize on the greatest herbage nutritive value at the top of the plant canopy. It is conceivable that the consumption of supplement with different NSC profile (starch vs. sucrose) may have influenced ruminal fermentation and post-ingestive feedback on grazing behavior (Provenza, 1995). In contrast, the time that cows spent ruminating or idling did not differ and averaged, respectively, 400 and $306 \mathrm{~min} / \mathrm{d}$ across treatments (Table 4).

\section{Milk Fatty Acid Profile}

Least squares means for the effects of treatments on the milk proportion of selected FA are presented in Table 5, and LSM for the milk proportions of all remaining SFA and UFA are presented in Supplemental Tables S3 and S4, respectively (https://doi.org/10 $.3168 /$ jds.2017-12618). Whereas the proportion of 4:0 in milk increased $(P=0.03)$ in cows fed $\mathrm{B}+\mathrm{GC}, 15: 0$ $(P<0.01), \Sigma$ odd-chain FA $(P<0.01), 6: 0(P=0.08)$, and $\Sigma 18 \mathrm{C}(P=0.06)$ increased or tended to increase in cows fed $\mathrm{B}+\mathrm{LM}$. Milk proportions of 11:0 $(P<$ $0.01)$ and 13:0 $(P<0.01)$ were also greatest in cows fed B+LM (Supplemental Table S3). Milk concentrations of odd- and branched-chain FA have been linked to ruminal function, including fermentation processes and microbial protein synthesis (Fievez et al., 2012). Thus, enhanced milk proportions of the odd-chain FA 11:0, 13:0, 15:0, and 17:0 with feeding B+LM suggest increased duodenal flow of microbial protein or that $\mathrm{B}+\mathrm{LM}$ supplementation favored the growth of microorganisms that synthesize odd-chain FA in the rumen. Surprisingly, amylolytic but not sugar-utilizing ruminal bacteria have been shown to be enriched in linear oddchain FA (Fievez et al., 2012). It is important to note, however, that the use of odd- and branched-chain FA as potential biomarkers of microbial protein synthesis has been recently challenged due to postruminal de novo synthesis or desaturation and elongation of these FA
(French et al., 2012; Vlaeminck et al., 2015). Therefore, inferences about the relationship between microbial protein synthesis and milk proportions of odd- and branched-chain FA should be made with caution.

The milk proportion of cis-9 18:1 was greatest in cows fed B+GC (Table 5), which may be explained by increased intake of cis-9 18:1, because ground corn is a rich source of this MUFA (Table 2). This hypothesis is reinforced by the fact that the $\Delta^{9}$-desaturase index 18 (cis-9 18:1/18:0; Supplemental Table S4; https:// doi.org/10.3168/jds.2017-12618) and $\Delta^{9}$-desaturase index $_{14}$ (cis-9 14:1/14:0; Supplemental Table S4) did not differ between treatments, suggesting similar endogenous production of cis-9 18:1. The $\Sigma$ cis-18:1 FA was greatest in $\mathrm{B}+\mathrm{GC}$ cows (Table 5 ) due to increased milk cis-9 18:1 as all remaining cis-18:1 FA were similar across diets (Supplemental Table S4). The milk proportions of trans-9 18:1, trans-12 18:1, and trans-15 18:1 reported in Supplemental Table S4, and trans-10 18:1 and the ratio of trans-11 18:1 to trans-10 18:1 reported in Table 5 all decreased significantly when feeding B+LM, which may be related to decreased intake of cis-9 18:1 and cis-9,cis-12 18:2 (Table 5). In studies where high forage (Brito et al., 2015) or high grain (Martel et al., 2011) rations were supplemented with liquid molasses as a substitute for ground corn, the milk proportion of trans-10 18:1 was also decreased.

The proportion of cis-9,cis-12,cis-15 18:3 in milk was greatest in cows fed $\mathrm{B}+\mathrm{LM}$ (Table 5). Herbage DMI and supplement DMI were greatest with feeding B+LM and may have accounted for increased milk cis-9, cis12,cis-15 18:3; herbage and baleage are better sources of this PUFA than is ground corn (Tables 1 and 2). The milk proportions of cis-5,cis-8,cis-11,cis-14,cis-17 20:5, cis-7,cis-10,cis-13,cis-16,cis-19 22:5, and cis-4,cis-7,cis10,cis-13,cis-16,cis-19 22:6 reported in Supplemental Table S4 were greatest in cows fed B+LM, probably due to elongation and desaturation reactions after absorption of cis-9,cis-12,cis-15 18:3 (Bernal-Santos et al., 2010). Although the $\Sigma$ n-6 FA in milk fat did not differ between treatments, the $\Sigma$ n-3 FA was greatest in $\mathrm{B}+\mathrm{LM}$ cows, resulting in a decreased n- 6 to $\mathrm{n}-3 \mathrm{FA}$ ratio.

\section{CONCLUSIONS}

Liquid molasses supplemented at a daily flat rate of $1.6 \mathrm{~kg}$ of DM per cow can entirely replace the same amount of ground corn when fed as the sole supplemental NSC source to grazing dairy cows without negatively affecting milk yield or concentrations and yields of milk fat and true protein, while decreasing MUN and PUN. Supplementation with $\mathrm{B}+\mathrm{GC}$ or $\mathrm{B}+\mathrm{LM}$ resulted in 
Table 5. Least squares means for milk proportions of selected individual fatty acids (FA) and sum and ratios of FA in lactating dairy cows grazing mixed grass-legume herbage supplemented with baleage plus ground corn $(\mathrm{B}+\mathrm{GC})$ or baleage plus liquid molasses $(\mathrm{B}+\mathrm{LM})^{1}$

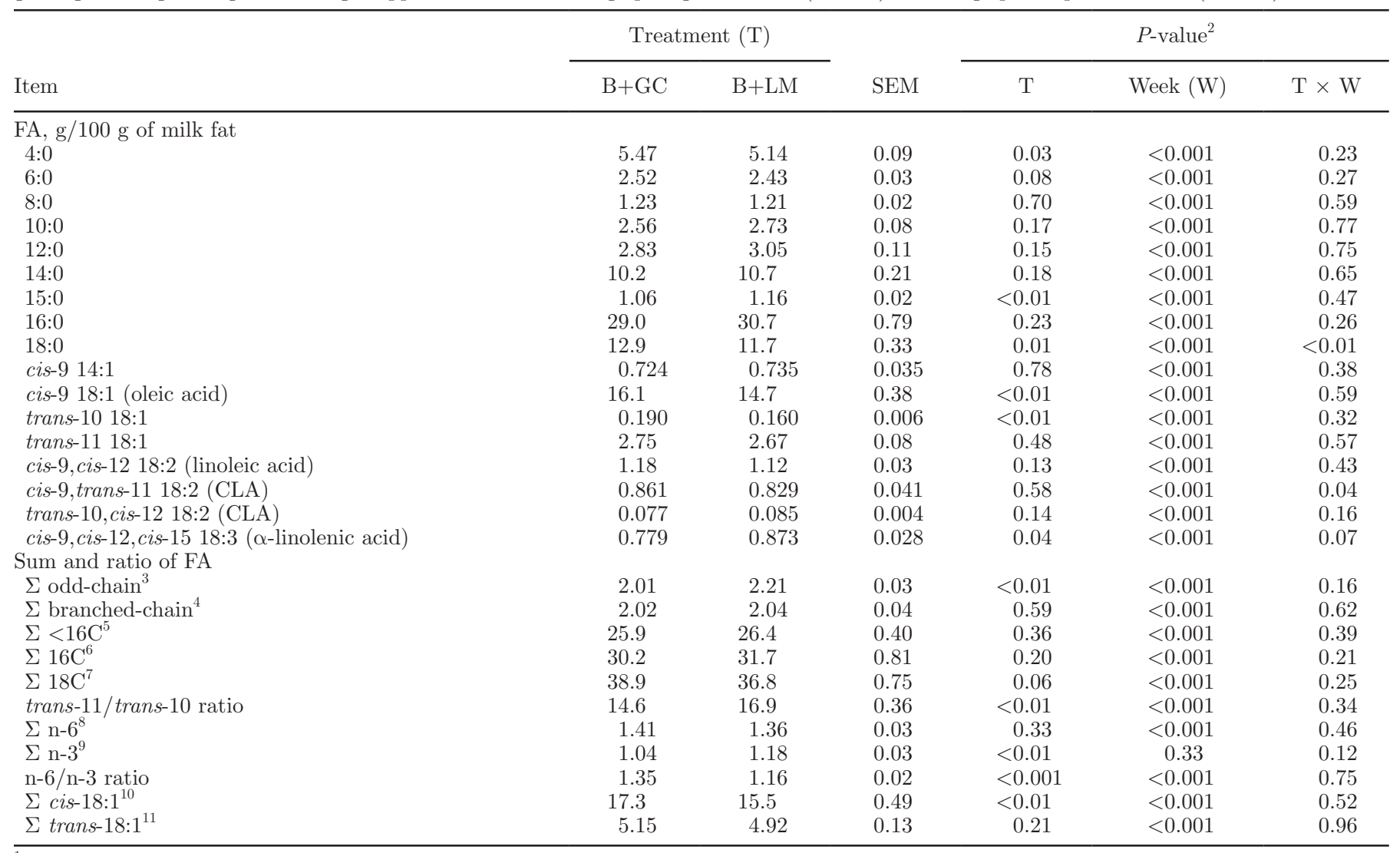

${ }^{1}$ Least squares means and SEM for the milk proportions of remaining SFA and UFA are reported in Supplemental Tables S3 and S4, respectively (https://doi.org/10.3168/jds.2017-12618).

${ }^{2}$ Significance was declared at $P \leq 0.05$ and trends at $0.05<P \leq 0.10$.

${ }^{3} \Sigma$ odd-chain FA $=15: 0$ (this table) + 11:0 + 13:0 + 17:0 + 19:0 (Supplemental Table S3) + cis-9 17:1 (Supplemental Table S4).

${ }^{4} \Sigma$ branched-chain FA $=$ iso 13:0 + anteiso 13:0 + iso 14:0 + iso 15:0 + anteiso 15:0 + iso 16:0 + iso 17:0 + anteiso 17:0 + iso 18:0 (Supplemental Table S3).

${ }^{5} \Sigma<16 \mathrm{C}$ FA (originate from de novo synthesis in the mammary gland) $=4: 0+6: 0+8: 0+10: 0+12: 0+14: 0+10: 1+12: 1+$ cis-9 14:1; these last 2 UFA are reported in Supplemental Table S4.

${ }^{6} \Sigma$ 16C FA (originate from de novo synthesis in the mammary gland and extraction from plasma) $=16: 0+$ all 16-C UFA reported in Supplemental Table S4.

${ }^{7} \Sigma 18$ C FA (originate from plasma extraction) $=18: 0+$ cis-9 18:1 + trans-10 18:1 + trans-11 18:1 + cis-9, cis- 12 18:2 + cis-9,trans-11 18:2, trans-10,cis-12 18:2 + cis-9,cis-12,cis-15 18:3 + all 18-C UFA reported in Supplemental Table S4.

${ }^{8} \Sigma \mathrm{n}-6 \mathrm{FA}=$ cis-9,cis-12 18:2 (this table) + cis-6,cis-9,cis-12 18:3 + cis-11,cis-14 20:2 + cis-8,cis-11,cis-14 20:3 + cis-5,cis-8,cis-11,cis-14 20:4 + cis-7,cis-10,cis-13,cis-16 22:4 + cis-4,cis-7,cis-10,cis-13,cis-16 22:5 (Supplemental Table S4).

${ }^{9} \Sigma \mathrm{n}-3 \mathrm{FA}=$ cis-9,cis-12,cis-15 18:3 (this table) + cis-6,cis-9,cis-12,cis-15 18:4 + cis-11,cis-14,cis-17 20:3 + cis-8,cis-11,cis-14,cis-17 20:4 + cis-5,cis-8,cis-11,cis-14,cis-17 20:5 + cis-13,cis-16,cis-19 22:3 + cis-7,cis-10,cis-13,cis-16,cis-1922:5 + cis-4,cis-7,cis-10,cis-13,cis-16,cis-19 22:6 (Supplemental Table S4).

${ }^{10} \Sigma$ cis-18:1 = cis-9 18:1 + all cis-18:1 FA reported in Supplemental Table S4.

${ }^{11} \Sigma$ trans-18:1 = trans-10 18:1 + trans-11 18:1 + all trans-18:1 FA reported in Supplemental Table S4.

varied responses in the proportions of milk FA, possibly due to differences in the intake of 18-C FA and shifts in ruminal biohydrogenation pathways. Further research is needed to better understand the potential interactions between the form of molasses administration and grazing behavior, as well as the role of molasses on ruminal biohydrogenation processes in high-sugar diets or when fed as the sole NSC supplemental source.

\section{ACKNOWLEDGMENTS}

Partial funding was provided by the New Hampshire Agricultural Experiment Station (Durham, NH; Scientific Contribution Number 2737) and USDA-Agricultural Research Service (ARS; Washington, DC). This work was also financially supported by the USDA-Northeast Sustainable Agriculture Research and Education 
(Grant Number GNE10-011), USDA-National Institute of Food and Agriculture (Hatch Multistate NC-1042 Project Number NH00616-R; Project Accession Number 1001855), Organic Farming Research Foundation, and the University of New Hampshire (UNH) Hamel Center for Undergraduate Research. Gratitude is extended to the technical assistance and laboratory analyses by Nancy Whitehouse (UNH; Durham, NH) and Caren Ghedini (UNH; Durham, NH), and former UNH (Durham, NH) students Kristen Greene (Hamel Center Summer Undergraduate Research Scholarship recipient) and Ashley Green for support during sample collection and laboratory analyses. We thank the UNH Burley-Demeritt Organic Dairy Research Farm former manager Trent Schrieffer and his staff for animal care and overall research support.

\section{REFERENCES}

AOAC International. 2016. Official Methods of Analyses. 20th ed. AOAC International, Gaithersburg, MD.

Bannink, A., H. Valk, and A. M. Van Vuuren. 1999. Intake and excretion of sodium, potassium, and nitrogen and the effects on urine production by lactating dairy cows. J. Dairy Sci. 82:1008-1018. https://doi.org/10.3168/jds.S0022-0302(99)75321-X.

Bargo, F., L. D. Muller, E. S. Kolver, and J. E. Delahoy. 2003. Invited Review: Production and digestion of supplemented dairy cows on pasture. J. Dairy Sci. 86:1-42. https://doi.org/10.3168/jds.S0022 -0302(03)73581-4.

Bernal-Santos, G., A. M. O'Donnell, J. L. Vicini, G. F. Hartnell, and D. E. Bauman. 2010. Hot topic: Enhancing omega-3 fatty acids in milk fat of dairy cows by using stearidonic acid-enriched soybean oil from genetically modified soybeans. J. Dairy Sci. 93:32-37. https://doi.org/10.3168/jds.2009-2711.

Boivin, M., R. Gervais, and P. Y. Chouinard. 2013. Effect of grain and forage fractions of corn silage on milk production and composition in dairy cows. Animal 7:245-254. https://doi.org/10.1017/ S1751731112001486.

Boufaïed, H., P. Y. Chouinard, G. F. Tremblay, H. V. Petit, R. Michaud, and G. Belanger. 2003. Fatty acids in forages. I. Factors affecting concentrations. Can. J. Anim. Sci. 83:501-511. https:// doi.org/10.4141/A02-098.

Brito, A. F., H. V. Petit, A. B. D. Pereira, K. J. Soder, and S. Ross. 2015. Interactions of corn meal or molasses with a soybean-sunflower meal mix or flaxseed meal on production, milk fatty acids composition, and nutrient utilization in dairy cows fed grass haybased diets. J. Dairy Sci. 98:443-457. https://doi.org/10.3168/jds .2014-8353.

Broderick, G. A., N. D. Luchini, S. M. Reynal, G. A. Varga, and V. A. Ishler. 2008. Effect on production of replacing dietary starch with sucrose in lactating dairy cows. J. Dairy Sci. 91:4801-4810. https://doi.org/10.3168/jds.2008-1480.

Broderick, G. A., and W. J. Radloff. 2004. Effect of molasses supplementation on the production of lactating dairy cows fed diets based on alfalfa and corn silage. J. Dairy Sci. 87:2997-3009. https://doi.org/10.3168/jds.S0022-0302(04)73431-1.

Chamberlain, D. G., S. Robertson, and J. J. Choung. 1993. Sugars versus starch as supplements to grass silage: Effects of ruminal fermentation and the supply of microbial protein to the small intestine, estimated from the urinary excretion of purine derivatives in sheep. J. Sci. Food Agric. 63:189-194. https://doi.org/10.1002/ jsfa.2740630204.

Chen, X. B., Y. K. Chen, M. F. Franklin, E. R. Ørskov, and W. J. Shand. 1992. The effect of feed intake and body weight on pu- rine derivative excretion and microbial protein supply in sheep. J. Anim. Sci. 70:1534-1542. https://doi.org/10.2527/1992.7051534x.

Chouinard, P. Y., J. Lévesque, V. Girard, and G. J. Brisson. 1997. Dietary soybeans extruded at different temperatures: Milk composition and in situ fatty acid reactions. J. Dairy Sci. 80:2913-2924. https://doi.org/10.3168/jds.S0022-0302(97)76257-X.

Craninx, M., A. Steen, H. Van Laar, T. Van Nespen, J. Martin-Tereso, B. De Baets, and V. Fievez. 2008. Effect of lactation stage on the odd- and branched-chain milk fatty acids of dairy cattle under grazing and indoor conditions. J. Dairy Sci. 91:2662-2677. https:// doi.org/10.3168/jds.2007-0656.

Deyl, Z., J. Hyanek, and M. Horakova. 1986. Profiling of amino acids in body fluids and tissues by means of liquid chromatography. J. Chromatogr. 379:177-250. https://doi.org/10.1016/S0378 $-4347(00) 80685-4$.

Dillard, S. L., A. N. Hafla, M. D. Rubano, R. C. Stout, A. F. Brito, and K. J. Soder. 2016. Evaluation of a rising plate meter for use in multispecies swards. Agric. Environ. Lett. 1:160032 https://doi .org/10.2134/ael2016.08.0032.

Eriksson, T., and B.-O. Rustas. 2014. Effects on milk urea concentration, urine output, and drinking water intake from incremental doses of potassium bicarbonate fed to mid-lactation dairy cows. J. Dairy Sci. 97:4471-4484. https://doi.org/10.3168/jds.2013-7861.

Fekkes, D. 1996. State-of-the-art of high-performance liquid chromatographic analysis of amino acids in physiological samples. J. Chromatogr. B Biomed. Appl. 682:3-22. https://doi.org/10.1016/0378 $-4347(96) 00057-6$.

Fievez, V., E. Colman, J. M. Castro-Montoya, I. Stefanov, and B. Vlaeminck. 2012. Milk odd- and branched-chain fatty acids as biomarkers of rumen function-An update. Anim. Feed Sci. Technol. 172:51-65. https://doi.org/10.1016/j.anifeedsci.2011.12.008.

French, E. A., S. J. Bertics, and L. E. Armentano. 2012. Rumen and milk odd- and branched-chain fatty acid proportions are minimally influenced by ruminal volatile fatty acid infusions. J. Dairy Sci. 95:2015-2026. https://doi.org/10.3168/jds.2011-4827.

Gaines, W. L., and F. A. Davidson. 1923. Relation between percentage fat content and yield of milk. Ill. Agric. Expt. Sta. Bull. 245.

Gehman, A. M., J. A. Bertrand, T. C. Jenkins, and B. W. Pinkerton. 2006. The effect of carbohydrate source on nitrogen capture in dairy cows. J. Dairy Sci. 89:2659-2667. https://doi.org/10.3168/ jds.S0022-0302(06)72342-6.

Ghedini, C. P., A. F. Brito, S. F. Reis, D. C. Moura, A. S. Oliveira, R. A. V. Santana, and A. B. D. Pereira. 2016. Liquid molasses decreases production linearly and changes enterolactone concentrations as a corn meal substitute in organic dairy cows fed flaxseed meal. Pages 1-8 in Proc. Organic Agric. Res. Symp., Pacific Grove, CA. http://eorganic.info/sites/eorganic.info/files/u27/4 .6-Ghedini\&al-2016-Replacing_Corn_Meal-OARS_Proceedings -Final.pdf.

Gregorini, P., S. A. Gunter, C. A. Masino, and P. A. Beck. 2007. Effects of ruminal fill on short-term herbage intake rate and grazing dynamics of beef heifers. Grass Forage Sci. 62:346-354. https://doi .org/10.1111/j.1365-2494.2007.00589.x.

Gregorini, P., K. J. Soder, and R. S. Kensinger. 2009. Effects of rumen fill on short-term intake ingestive behavior and circulating concentrations of ghrelin, insulin, and glucose of dairy cows foraging vegetative micro-swards. J. Dairy Sci. 92:2095-2105. https://doi .org $/ 10.3168 /$ jds. $2008-1803$.

Hafla, A. N., K. J. Soder, A. F. Brito, R. Kersbergen, A. F. Benson, H. M. Darby, M. D. Rubano, and S. F. Reis. 2016. Case study: Feeding strategy and pasture quality relative to nutrient requirements of dairy cows in the northeastern United States. Prof. Anim. Sci. 32:523-530. https://doi.org/10.15232/pas.2015-01500.

Heck, J. M. L., H. J. F. van Valenberg, J. Dijkstra, and A. C. M. van Hooijdonk. 2009. Seasonal variation in the Dutch bovine raw milk composition. J. Dairy Sci. 92:4745-4755. https://doi.org/10.3168/ jds.2009-2146.

Higgs, R. J., A. J. Sheahan, K. Mandok, M. E. Van Amburgh, and J. R. Roche. 2013. The effect of starch-, fiber-, or sugar-based supplements on nitrogen utilization in grazing dairy cows. J. Dairy Sci. 96:3857-3866. https://doi.org/10.3168/jds.2012-6117. 
Kolver, E. S., and L. D. Muller. 1998. Performance and nutrient intake of high producing Holstein cows consuming pasture or a total mixed ration. J. Dairy Sci. 81:1403-1411. https://doi.org/10.3168/ jds.S0022-0302(98)75704-2.

Martel, C. A., E. C. Titgemeyer, L. K. Mamedova, and B. J. Bradford. 2011. Dietary molasses increases ruminal $\mathrm{pH}$ and enhances ruminal biohydrogenation during milk fat depression. J. Dairy Sci. 94:3995-4004. https://doi.org/10.3168/jds.2011-4178.

Mir, P. S., S. Bittman, D. Hunt, T. Entz, and B. Yip. 2006. Lipid content and fatty acid composition of grasses sampled on different dates through the early part of the growing season. Can. J. Anim. Sci. 86:279-290. https://doi.org/10.4141/A05-050.

NRC. 2001. Nutrient Requirements of Dairy Cattle. 7th rev. ed. Natl. Acad. Sci., Washington, DC.

Nombekela, S. W., M. R. Murphy, H. W. Gonyou, and J. I. Marden. 1994. Dietary preferences in early lactation cows as affected by primary tastes and some common feed flavors. J. Dairy Sci. 77:23932399. https://doi.org/10.3168/jds.S0022-0302(94)77182-4.

Orth, R. 1992. Sample Day and Lactation Report. DHIA 200 FactSheet A-2. Mid-States Dairy Records Processing Center (DRPC), Ames, IA.

Provenza, F. D. 1995. Postingestive feedback as an elementary determinant of food preference and intake in ruminants. J. Range Manage. 48:2-17. https://doi.org/10.2307/4002498.

Resende, T. L., J. Kraft, K. J. Soder, A. B. D. Pereira, D. E. Woitschach, R. B. Reis, and A. F. Brito. 2015. Incremental amounts of ground flaxseed decrease milk yield but increase n-3 fatty acids and conjugated linoleic acids in dairy cows fed high-forage diets. J. Dairy Sci. 98:4785-4799. https://doi.org/10.3168/jds.2014-9115.

Ribeiro, C. V. D. M., S. K. R. Karnati, and M. L. Eastridge. 2005. Biohydrogenation of fatty acids and digestibility of fresh alfalfa or alfalfa hay plus sucrose in continuous culture. J. Dairy Sci. 88:4007-4017. https://doi.org/10.3168/jds.S0022-0302(05)73087 $-3$.

Rosenthal, H. L. 1955. Determination of urea in blood and urine with diacetyl monoxime. Anal. Chem. 27:1980-1982. https://doi.org/10 $.1021 /$ ac60108a039.

Rutter, S. M. 2000. Graze: A program to analyze recordings of jaw movements of ruminants. Behav. Res. Methods Instrum. Comput. 32:86-92. https://doi.org/10.3758/BF03200791.

Rutter, S. M., R. A. Champion, and P. D. Penning. 1997. An automatic system to record foraging behaviour in free-ranging ruminants. Appl. Anim. Behav. Sci. 54:185-195. https://doi.org/10 .1016/S0168-1591(96)01191-4.
Schwendel, B. H., T. J. Wester, P. C. H. Morel, M. H. Tavendale C. Deadman, N. M. Shadbolt, and D. E. Otter. 2015. Invited review: Organic and conventionally produced milk-An evaluation of factors influencing milk composition. J. Dairy Sci. 98:721-746. https://doi.org/10.3168/jds.2014-8389.

Siverson, A., C. F. Vargas-Rodriguez, and B. J. Bradford. 2014. Short communication: Effects of molasses products on productivity and milk fatty acid profile of cows fed diets high in dried distillers grains with solubles. J. Dairy Sci. 97:3860-3865. https://doi.org/ 10.3168/jds.2014-7902

Soder, K. J., K. Hoffman, L. E. Chase, and M. D. Rubano. 2012. Case study: Molasses as the primary energy supplement on an organic grazing dairy farm. Prof. Anim. Sci. 28:234-243. https://doi.org/ 10.15232/S1080-7446(15)30345-4.

Soder, K. J., M. A. Sanderson, J. L. Stack, and L. D. Muller. 2006. Intake and performance of lactating cows grazing diverse forage mixtures. J. Dairy Sci. 89:2158-2167. https://doi.org/10.3168/jds .S0022-0302(06)72286-X.

Soyeurt, H., P. Dardenne, F. Dehareng, C. Bastin, and N. Gengler. 2008. Genetic parameters of saturated and monounsaturated fatty acid content and the ratio of saturated to unsaturated fatty acids in bovine milk. J. Dairy Sci. 91:3611-3626. https://doi.org/10 $.3168 /$ jds.2007-0971

Spek, J. W., A. Bannink, G. Gort, W. H. Hendriks, and J. Dijkstra 2012. Effect of sodium chloride intake on urine volume, urinary urea excretion, and milk urea concentration in lactating dairy cattle. J. Dairy Sci. 95:7288-7298. https://doi.org/10.3168/jds.2012 -5688 .

Sukhija, P. S., and D. L. Palmquist. 1988. Rapid method for determination of total fatty acid content and composition of feedstuffs and feces. J. Agric. Food Chem. 36:1202-1206. https://doi.org/10 $.1021 /$ jf00084a019.

Valadares, R. F. D., G. A. Broderick, S. C. Valadares Filho, and M. K. Clayton. 1999. Effect of replacing alfalfa silage with high moisture corn on ruminal protein synthesis estimated from excretion of total purine derivatives. J. Dairy Sci. 82:2686-2696. https://doi.org/10 .3168/jds.S0022-0302(99)75525-6.

Vlaeminck, B., R. Gervais, M. M. Rahman, F. Gadeyne, M. Gorniak, M. Doreau, and V. Fievez. 2015. Postruminal synthesis modifies the odd- and branched-chain fatty acid profile from the duodenum to milk. J. Dairy Sci. 98:4829-4840. https://doi.org/10.3168/jds .2014-9207. 